$5-7-2020$

\title{
Visions of Greater Serbia: Local Dynamics and the Prijedor Genocide
}

Damir Kovačević

University of Wisconsin - Eau Claire

Follow this and additional works at: https://digitalcommons.usf.edu/gsp

\section{Recommended Citation}

Kovačević, Damir (2020) "Visions of Greater Serbia: Local Dynamics and the Prijedor Genocide," Genocide Studies and Prevention: An International Journal: Vol. 14: Iss. 1: 105-123.

DOI:

https://doi.org/10.5038/1911-9933.14.1.1686

Available at: https://digitalcommons.usf.edu/gsp/vol14/iss1/9

This Articles is brought to you for free and open access by the Open Access Journals at Digital Commons @ University of South Florida. It has been accepted for inclusion in Genocide Studies and Prevention: An International Journal by an authorized editor of Digital Commons @ University of South Florida. For more information, please contact digitalcommons@usf.edu. 


\title{
Visions of Greater Serbia: Local Dynamics and the Prijedor Genocide
}

\author{
Damir Kovačević \\ University of Wisconsin \\ Eau Claire, Wisconsin, USA
}

When the academic community, media, or policy experts mention the Bosnian genocide, it is unclear what they are referring to. Their reference to the event is often twofold. First, the term focuses on the macro-level, failing to disaggregate the intensity, location, and timing of violence. In other words, the term is used unwittingly to lump various events into a single, coherent story. The problem is that by lumping events into a unified story, the idiosyncrasies that define the various localities are lost in exchange for a simplified understanding of a rather complex and dynamic phenomenon. Second, the term is commonly used in reference to the atrocities committed in Srebrenica. Though this event is noteworthy and stands as the quintessential example of the type of violence the international community vowed would never again happen, it does not give a full account of what occurred during the war.

By taking a closer look at the meso-level, we see that the genocide in Bosnia was a coordinated campaign that extended across numerous municipalities, varying in time of execution and severity. The meso-level is a tool that studies violence at an analytical level below the nation-state. ${ }^{1}$ Aside from offering insights into subnational regions and localities, the meso-level is also "the least developed among the three prongs of genocide research." ${ }^{2}$ For the purposes of this paper, I utilize the meso-level to investigate the episode of genocide that unfolded in the municipality of Prijedor in the spring and summer of 1992. ${ }^{3}$ The case of Prijedor is important for several reasons. First, Prijedor accounted for the most deaths in northwestern Bosnia, and the third most deaths out of any municipality during the war. ${ }^{4}$ Second, Prijedor was situated in the strategically important location known as the Serbian Arc, where the Bosnian Serbs sought to link the Bosnian Serb populations of Serbia proper, eastern Bosnia, northwestern Bosnia, and Croatia, under the Greater Serbia umbrella..$^{5}$ Third, Prijedor accounted for a total of twenty-eight concentration camps - a significantly high number that included the notorious camps of Keraterm and Omarska. ${ }^{6}$

I argue that structural control and agent collaboration highlight the factors that contributed to the escalation and radicalization of violence to genocide in Prijedor. This causal argument

${ }^{1}$ Charles King, "The Micropolitics of Social Violence," World Politics 56, no. 1 (2004), 431-455, accessed March 27, 2019, https://doi.org/10.1353/wp.2004.0016.

${ }^{2}$ Evgeny Finkel and Scott Straus, "Macro, Meso, and Micro Research on Genocide: Gains, Shortcomings, and Future Areas of Inquiry," Genocide Studies and Prevention: An International Journal 7, no. 1 (2012), 59, accessed February 1, 2019, https://doi/.org/10.3138/gsp.7.1.56. Although this analytical level is underdeveloped, crucial research relating to genocide in Rwanda and civil war violence in Bosnia has been conducted. On the importance of local elites in the Bosnian civil war, see Fotini Christia, "Following the Money: Muslims versus Muslims in Bosnia's Civil War," Comparative Politics 40, no. 4 (2008), 461-480, accessed March 25, 2019, https://doi.org/10.5129/00104150 8X12911362383390. On the patterns of mass violence in Eastern Bosnia, see Edina Bećirević, Genocide on the Drina River (New Haven, CT: Yale University Press, 2014). On subnational violence and genocide in Rwanda, see Lee Ann Fujii, Killing Neighbors: Webs of Violence in Rwanda (Ithaca, NY: Cornell University Press, 2009); Scott Straus, The Order of Genocide: Race, Power, and War in Rwanda (Ithaca, NY: Cornell University Press, 2006).

${ }^{3}$ It is important to note that there have been many prosecutions for crimes committed in Prijedor by the ICTY, most notably the cases of Radovan Karadžić and Ratko Mladić, but the court has deemed these crimes short of genocide. In fact, from an international legal perspective, only the case of Srebrenica was deemed genocide.

${ }^{4}$ Patrick Ball et al., The Bosnian Book of the Dead: Assessment of the Database (Full Report) (Falmer, United Kingdom: The Institute of Development Studies, 2007), accessed March 27, 2019, http://www.hicn.org/wordpress/wp-content/ uploads/2012/07/rdn5.pdf.

${ }^{5}$ Guido Acquaviva, “Robert Donia, From the Republika Srpska Assembly 1991-1996: Excerpts from Delegates' Speeches at the Republika Srpska Assembly as Body of Evidence for the International Criminal Tribunal at The Hague," Journal of International Criminal Justice 11, no. 1 (September 2013), 931-951, accessed March 25, 2019, https://doi.org/10.1093/jicj/ $\underline{\text { mqt049. }}$.

${ }^{6}$ United Nations Security Council (UNSC), The Final Report of the Commission of Experts Established Pursuant to Security Council Resolution 780, December 28, 1994 (UN Doc. S/1994/674/Annex VIII, Prison Camps), 22; 185-267. The report lists 36 total camps, but only 28 that can be corroborated. It is also important to note that there were vast differences between concentration camps. Some were larger in size, whereas others were garages and smaller spaces. Pages 185267 of the report include a more detailed account of the concentration camps. 
emphasizes why Bosnian Serb elites - national, local, military, and paramilitary - were able to achieve the goals of Greater Serbia by combining their efforts through effective political and territorial dominance of Prijedor. This theoretical contribution is critical for several reasons. First, it builds on the existing literature in the strategic and ideological paradigms proposed by secondgeneration genocide scholars. However, it deviates on causal grounds. War (as proposed by the strategic paradigm) and exclusionary ideology are important to the story, but not as explanatory variables. War and exclusionary ideology set the stage for which cases are more likely to intensify, but to explain how and why violence ultimately escalates to genocide, we need to consider the dynamic relationship between structural factors and agents. Second, it suggests that previously established causal mechanisms pertinent to the national level may not apply to the local level. Thus, I intend to highlight how political authority, territorial bases, and the participation of local elites, are more suitable for explaining genocide at the subnational level.

\section{Genocide: A Multi-Dimensional Conceptualization}

Genocide has attracted considerable scholarly attention across the humanities, legal studies, and social sciences. Unpacking the various conceptual disagreements is beyond the focus of this paper, but it is an area that deserves development, if scholars want to speak to each other across and within disciplines. ${ }^{7}$ For this paper, I employ Scott Straus' definition of genocide. Genocide is "large-scale, organized, group-destructive violence that targets a specific social group in a territory." ${ }^{8}$ This definition distinguishes genocide from other forms of political violence based on two characteristics: group-selectivity and group-destructiveness. ${ }^{9}$

Moreover, I conceptualize genocide as part of a multi-dimensional political violence framework where different tiers of intensity and group-targeting are possible. The purpose of such a dimension is to illustrate that genocide is a process of violence that perpetrators may escalate to over time. It can occur in the early stages of violence, later into the fighting, and in some instances, we may even see a de-escalation of violence. By understanding genocide as a process, we can move beyond the notion that it is a fixed event, or an isolated incident that can be studied independently of the greater political violence context. Perpetrators have an array of strategies in the political violence process, and my goal is to understand how and why the most extreme strategy unfolds. One dimension of the political violence framework includes the level of intensity. Limited violence represents the lowest level of intensity, while a full-scale war represents the highest level of intensity. The second dimension includes levels of group-targeting. In cases where groups are not targeted, we should see regular, combatant-targeted violence ranging in levels of intensity, while cases of group-targeting should range anywhere from discriminatory and exclusionary social policies directed at a specific group to mass killings or genocide.

\footnotetext{
${ }^{7}$ For an interdisciplinary review of genocide, see: Donald Bloxham and A. Dirk Moses, The Oxford Handbook of Genocide Studies (Oxford: Oxford University Press, 2010).

${ }^{8}$ Scott Straus, "Retreating from the Brink: Theorizing Mass Violence and the Dynamics of Restraint," Perspectives on Politics 10, no. 2 (2012), 345, accessed March 25, 2019, https://doi.org/10.1017/S1537592712000709.

${ }^{9}$ Scott Straus, who has pioneered the study of subnational variation in genocide studies identifies genocide along the lines of group-selectivity and group-destructiveness. For further reading, see Scott Straus, Making and Unmaking Nations: War Leadership, and Genocide in Modern Africa (Ithaca, NY: Cornell University Press 2015), 20-24.
} 


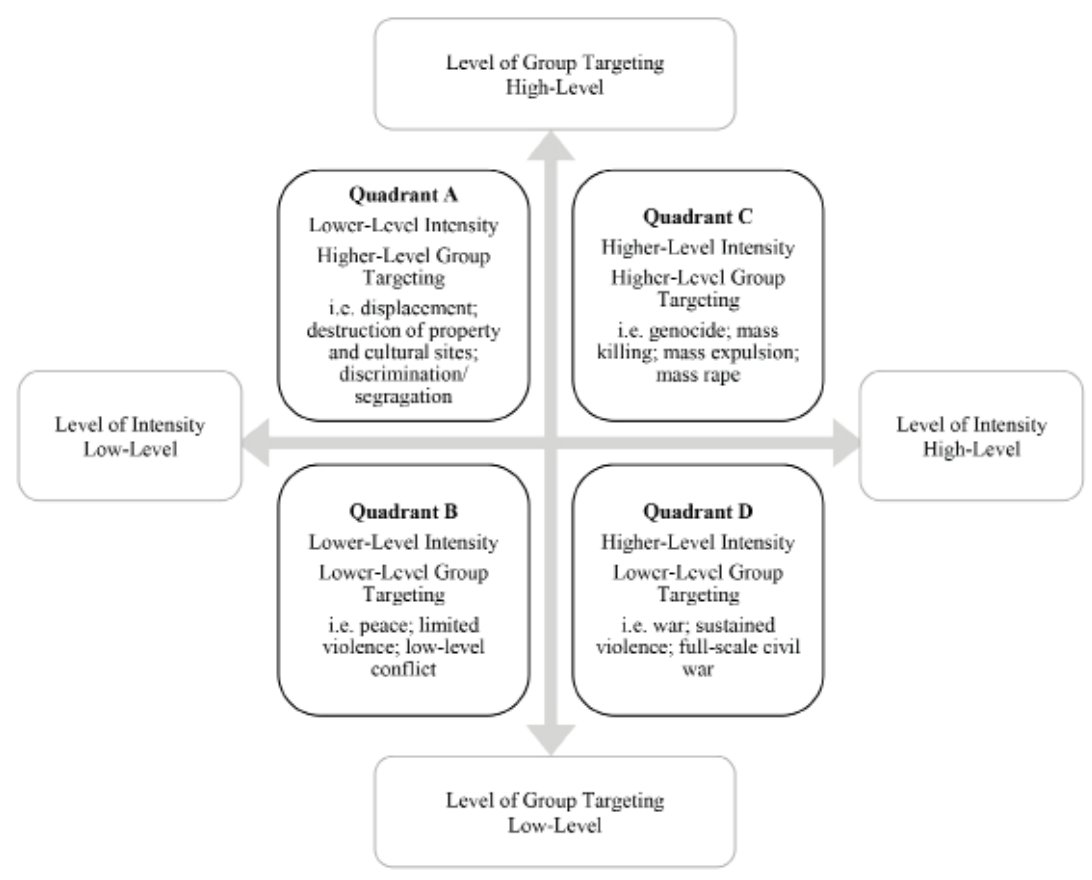

Figure 1. Political Violence Framework

This framework establishes four quadrants applicable to the universe of political violence cases. For this paper, I am specifically interested in Quadrant C. I focus on why the case of Prijedor was not Quadrant D violence, like the siege of Sarajevo, for instance, which represents a case of civil war violence between combatant groups. ${ }^{10}$ Relatedly, I focus on the factors that account for escalation and radicalization of violence in Prijedor, whereby the perpetrators engaged in highintensity violence, but rather than confining their violence to the traditional theater of warfare, they committed genocide against an ethno-religious group. ${ }^{11}$

\section{Strategy, Ideology, and Shortcomings}

The development of genocide literature within the discipline of political science has evolved from traditional explanations focusing on ancient hatreds, authoritarian regimes, and scapegoating, to the dominant camps centered on the strategic and ideological paradigm. ${ }^{12}$ The strategic paradigm views policies of genocide and mass violence developing in response to real or perceived threats and generally occurring during times of internal instability or warfare. ${ }^{13}$ Benjamin Valentino

${ }^{10}$ UNSC, The Final Report of the Commission of Experts Established Pursuant to Security Council Resolution 780, December 28, 1994 (UN Doc. S/1994/674/Annex V, The Prijedor Report), 101.

${ }^{11}$ For other helpful frameworks, see Anthony W. Marx, “The Nation-State and Its Exclusions," Political Science Quarterly 17, no. 1 (2002), 103-126, accessed March 27, 2019, https://doi.org/10.2307/798096; and Straus, Retreating from the Brink, 343-362, accessed March 25, 2019, https://doi.org/10.1017/S1537592712000709.

Marx examines cases of exclusionary nationalism but leaves out "ultimate exclusion" or genocide from his framework and argues it deserves a distinct analysis. Straus provides a "Ladder of Violence," which shows the factors of escalation and restraint. Leaders can move down the ladder and increase levels of violence or move up the ladder and decrease levels of violence.

${ }^{12}$ For first-generation research on intergroup prejudices and divisions, see Helen Fein, Accounting for Genocide: National Responses and Jewish Victimization during the Holocaust (Chicago: Chicago University Press, 1979); Leo Kuper, Genocide: Its Political Use in the Twentieth Century (New Haven: Yale University Press, 1981). For first-generation literature on authoritarian regimes, see Irving Louis Horowitz, Genocide: State Power and Mass Murder (New Brunswick: Transaction, 1976). For first-generation literature on scapegoating, see Ervin Staub, The Roots of Evil: The Origins of Genocide and Other Group Violence (Cambridge: Cambridge University Press, 1989).

${ }^{13}$ Barbara Harff, "No Lessons Learned from the Holocaust? Assessing Risks of Genocide and Political Mass Murder since 1955," American Political Science Review 97, no. 1 (2003), 57-73, accessed March 27, 2019, https://doi.org/10.1017/ 
posits that genocide is more likely to occur during war because of the uncertainty and threats perceived by elites. Therefore, elites - both military and political - are critical for organizing mass violence because of their own beliefs, fears, hatreds, or interests, and are driven by instrumental, strategic calculations in pursuit of their goals. ${ }^{14}$ Manus Midlarsky argues that elites will perpetrate genocide in the context of loss, especially territorial. The presence of war leads to instability and vulnerability amongst groups, and when these groups suffer losses during wartime, they are more likely to engage in "imprudent realpolitik" by framing civilian groups as enemies and threats. Thus, the strategic paradigm draws several conclusions linking war to genocide: war creates threat and uncertainty, and threat and uncertainty increase the likelihood that violence will be used in response. Also, war increases the likelihood that members of the opposing group will be labeled as enemies, which will prompt the use of military violence against the perceived or real enemy. ${ }^{15}$

On the other hand, scholars situated within the ideological paradigm argue that to understand genocide, one needs to understand the ideologies that manifest in the thought process of elites. Elites possess certain ideological visions that constitute a legitimate form of the state. Certain groups fit this standard, while other groups pose a threat to the purity or utopia of an ethnically or religiously homogeneous society. Jacques Sémelin posits that leaders seek to exterminate social groups from certain territories to purify their own group and society. To accomplish this, elites will seek to unify in-groups to create fear and hostility toward out-groups, or enemies. By stressing unity, efforts to create purity lead to desires to eliminate these out-groups. ${ }^{16}$ Eric Weitz argues that leaders have grand ideological quests for utopian societies based on common group characteristics. The leaders see themselves as revolutionaries seeking a better future based on extreme exclusionary policies. ${ }^{17}$ These themes are also present in Ben Kiernan's historical account of genocide from ancient Sparta to modern-day Darfur. Kiernan establishes four salient features and patterns that are present in nearly every case of mass violence: cults of antiquity, agrarianism, racism or religious prejudice, and territorial expansion. ${ }^{18}$

So, what is missing? What is it about ideology and strategy that fails to explain the onset and process of genocide? For one, both include explanatory variables that occur more often than genocide. Although the strategic paradigm has made significant strides in emphasizing the importance of warfare as the backdrop for genocide, wars are still more common than genocide. How do we account for the non-cases of genocide that had similar patterns of warfare present? Additionally, the strategic paradigm fails to address two other important questions: Why are civilian groups targeted and why is the goal to eradicate these groups from the specific territory ${ }^{19}$ The ideological paradigm seems to answer these questions partially. Civilian groups are targeted because they are seen as part of an illegitimate out-group, threatening the existence of the in-group and prospects for a homogenized society. However, just like the presence of warfare, extreme ideologies are also more common than genocide. What about those cases where elites possess extreme notions of ingroup and out-group dynamics but do not or cannot initiate genocidal violence?

S0003055403000522; Matthew Krain, "State-Sponsored Mass Murder: The Onset and Severity of Genocides and Politicides," Journal of Conflict Resolution 41, no. 3 (1997), 331-360, accessed March 27, 2019, https://doi.org/10.1177\% 2F0022002797041003001; Manus Midlarsky, The Killing Trip: Genocide in the Twentieth Century (New York: Cambridge University Press, 2005); Martin Shaw, War and Genocide: Organized Killing in Modern Society (Cambridge: Polity, 2003); Jay Ulfelder and Benjamin Valentino, Assessing Risks of State-Sponsored Mass Killing (Washington, DC: Political Instability Task Force, 2008), accessed March 27, 2019, https://papers.ssrn.com/sol3/papers.cfm?abstract id=1703426.

${ }^{14}$ Benjamin Valentino, Final Solutions: Mass Killing and Genocide in the Twentieth Century (Ithaca, NY: Cornell University Press, 2004).

${ }^{15}$ Scott Straus, "Destroy Them to Save Us: Theories of Genocide and the Logics of Political Violence," Terrorism and Political Violence 24, no. 4 (2012), 547-548, accessed March 27, 2019, https://psycnet.apa.org/doi/10.1080/09546553.2012. 700611.

${ }^{16}$ Jacques Sémelin, Purify and Destroy: The Political Uses of Massacre and Genocide (London: Hurst \& Company, 2005$), 91$.

${ }^{17}$ Eric Weitz, A Century of Genocide: Utopias of Race and Nation (Princeton: Princeton University Press, 2003), 14.

${ }^{18}$ Ben Kiernan, Blood and Soil: A World History of Genocide and Extermination from Sparta to Darfur (New Haven: Yale University Press, 2009).

${ }^{19}$ Straus, Destroy Them to Save Us, 547. 
It is likely, as Straus argues, that these paradigms should complement one another in seeking to explain genocide. ${ }^{20}$ Although I do not disagree that these paradigms do a better job explaining such a rare event together rather than independently, I argue that they do not present the causal mechanisms for explaining how and why genocide was executed completely. To do this, I turn to the discussion of the meso-level before presenting two additional factors, structural control and agent collaboration, in explaining the escalation and radicalization to genocide.

\section{Meso-Level Analysis}

The aforementioned literature almost exclusively focuses on the national level of analysis to explain genocide. A common theme is to select major twentieth-century cases and compare them. Although this has increased our empirical and theoretical understandings of this dynamic type of violence, it has also led to what Barbara Geddes refers to as "the selection bias in comparative politics." ${ }^{21}$ By selecting on the dependent variable, scholars are justifying their case selection strategies on cases that share a common outcome, rather than common features that may have led to differing outcomes. One way to remedy this is to study negative cases, a solution proposed to scholars working in the comparative genocide literature. ${ }^{22}$ By studying the non-cases of genocide, scholars can determine which conditions are more likely to lead to genocide through careful, and methodologically strong, controlled-comparisons.

Another issue that arises is the neglect of the local level. Referring to an event as the Armenian, Bosnian, or Rwandan genocide does not account for variation within those specific cases. Where in Bosnia did genocide occur? What was the timing and severity of the violence in a specific municipality? What local actors played a crucial role? How did they interact with national actors and various state institutions to carry out this violence? To answer these questions, another strategy, as argued on the onset of this paper, is to narrow the focus to a more intimate level of analysis. Therefore, a subnational analysis serves as another remedy. As argued by Charles King,

episodes of social violence, whether riots or atrocities committed during civil wars, may well be patterned, but they do not occur uniformly across time or space. There are lulls and peaks. Violence comes to different cities, towns, and neighborhoods at different times. It plays out differently in various social contexts, even with a series of violent events that are lumped together as a single ethnic conflict or civil war. ${ }^{23}$

Rather than simply referring to the violence in Bosnia as the Bosnian genocide or equating it with the event at Srebrenica, I seek to examine the episode of Prijedor to better understand how and why violence escalated. Particularly, I want to know why violence reached high-levels of intensity and group-targeting, making Prijedor one of the deadliest municipalities during the war, with a significantly high number of concentration camps. By doing so, national level factors - government institutions, national leaders, and presence of internal instability and war - remain constant, and the importance of locality, and particularly the role of local elites can be examined. By bringing in the role of local elites and how they interact with national elites and institutions, we can begin to understand the phenomenon of genocide more holistically.

Scholars working in the tradition of political violence have employed such a technique to gain new empirical and theoretical insights into civil war violence, intercommunal rioting, and genocide. ${ }^{24}$ My goal is to use a similar methodological technique to gain additional empirical and

${ }^{20}$ Straus, Making and Unmaking Nations, 55-59; Straus, Destroy Them to Save Us, 549-550.

${ }^{21}$ Barbara Geddes, "How the Cases You Choose Affect the Answers You Get: Selection Bias in Comparative Politics," Political Analysis 2, no. 1 (1990), 131-150, accessed March 27, 2019, https://doi.org/10.1093/pan/2.1.131.

${ }^{22}$ Finkel and Straus, Macro, Meso, and Micro Research on Genocide, 63; Straus, Destroy Them to Save Us, 555; Ernesto Verdeja, "On Situating the Study of Genocide within Political Violence," Genocide Studies and Prevention: An International Journal 7, no. 1 (2012), 83-84, accessed March 25, 2019, https://doi.org/10.3138/gsp.7.1.81.

${ }^{23}$ King, The Micropolitics of Social Violence, 447.

${ }^{24}$ Ashutosh Varshney, Ethnic Conflict and Civic Life: Hindus and Muslims in India (New Haven: Yale University Press, 2002); Stathis Kalyvas, The Logic of Violence in Civil War (Cambridge: Cambridge University Press, 2006); Straus, The Order of 
theoretical insights into an underdeveloped case. Although my analysis is a single-case study, I propose that the "micro-political turn," to quote King, allows me to account for causal mechanisms missing when simply looking at the national level. This preliminary theoretical exploration can serve as a step for future comparative subnational analyses across other municipalities in Bosnia, and even other countries and regions..$^{25}$

\section{Argument}

Before delving into the argument, it is important to emphasize the role the ideological and strategic paradigms have in explaining the phenomenon of genocide. Their complementary nature is a step forward, not as explanatory variables, but rather as scope conditions. As scope conditions, both the strategic and ideological paradigms specify the parameters to which the causal argument applies. In other words, by identifying cases of internal instability and/or war, whereby elites exhibit exclusionary ideologies of in-group and out-group dynamics, researchers can establish a proper universe of "at-risk" cases. These cases should be alarming and should signal to the researcher or policymaker that certain conditions are in place for what could be a future case of genocide.

Wars favor genocide because they justify killings as a policy. The perpetrators of the violence see out-groups as enemies, leading to fear and uncertainty, and ultimately a legitimization to use violence to eliminate the perceived or real threat. The empirical reality confirms this: genocide most always exists in the context of warfare. ${ }^{26}$ That being said, the presence of war still greatly exceeds the presence of genocide. War does not effectively explain cases under similar conditions that never led to genocide.

Additionally, exclusionary ideology is the "totalizing system of meaning based on pronounced in-group and out-group distinctions permitting no shared forms of identification between groups and premised on a radical devaluation of the out-group." 27 The dangers of elites harboring exclusionary ideologies are twofold. First, these ideologies create immense divides between different social groups. The in-group is seen as a legitimate part of the envisioned state and the out-group is seen as illegitimate. Second, exclusivist ideologies seek to target and dehumanize outgroups through various methods ranging from discrimination to forced assimilation or expulsion. As Verdeja notes, exclusivist ideology "achieves its greatest resonance when it exaggerates, and perverts already recognized differences between groups. ${ }^{28}$ But if elites harbor exclusionary and fanatical ideas, and wish to act on these, what allows them to achieve their goals of eliminating the out-group? And if the presence of war overdetermines genocide, what other factors are necessary to explain a rare, but extraordinary phenomenon?

To build on these scope conditions, I posit that the presence of structural control and agent collaboration help us understand which "at-risk" cases could spiral into genocidal violence. Structural control refers to adequate political authority and territorial bases. Adequate political authority may include effective political institutions, weak state capacity, total collapse of an effective central government, and support from neighboring states or other international allies to mobilize against possible suppression from the state. ${ }^{29}$ If elites within a group are the main perpetrator of the violence, then we should expect them to establish effective political institutions that rival the state or are in place of a failing or failed state government. The group may also be supported by a nearby ally that offers military power and resources to thwart the current regime.

Genocide; Fujii, Killing Neighbors.

${ }^{25}$ For other relevant readings on the Former Yugoslavia, see Nina Caspersen, Contested Nationalism: Serb Elite Rivalry in Croatia and Bosnia in the 1990s (New York: Berghahn Books, 2010); Dennis Gratz, "Elitocide in Bosnia and Herzegovina and Its Impact on the Contemporary Understanding of the Crime of Genocide," The Journal of Nationalism and Ethnicity 39, no. 3 (2011), 409-424; Adis Maksić, Ethnic Mobilization, Violence, and the Politics of Affect: The Serb Democratic Party and the Bosnian War (London: Palgrave Macmillan, 2017).

${ }^{26}$ Harff, No Lessons Learned from the Holocaust?. In her quantitative analysis, Harff finds that out of 37 cases of genocide between 1955 to 1998, "all but one occurred during or immediately after political upheaval."

${ }^{27}$ Verdeja, The Political Science of Genocide, 315.

${ }^{28} \mathrm{Ibid}$.

${ }^{29}$ Stuart Kaufman, "Symbolic Politics or Rational Choice? Testing Theories of Extreme Ethnic Violence," International Security 30, no. 4 (2006), 53, accessed March 27, 2019, https://doi.org/10.1162/isec.2006.30.4.45. 
If the state is the main perpetrator of violence, then we should expect a lack of effective opposition since the state is already in power and more dominant than any potential opposing group. In this case, the state will have control of political institutions and might also be supported by neighboring states. By perpetrating the violence, we would expect a functioning central government capable of exerting force against targeted groups with little to no resistance.

Elites within a groups must also have territorial bases to effectively mobilize, whether within the state or in a neighboring country. ${ }^{30}$ Again, if the state is the main perpetrator of the violence, then it will not have an issue with establishing territorial bases since the state's entire territory should be the base. But for elites in groups seeking to perpetrate violence, it is crucial that they have effective military positions to mobilize personnel and escalate their violence against the outgroup.

Thus, structural control - political authority and territorial base(s) - increases the likelihood that wars will escalate to genocide. If elites do not possess effective political authority and territorial bases, they will most likely be in several disadvantageous positions. It could be that the group or state is overpowered and their goals of executing more extreme violence are upended. It could also be that the group or state is in a two-sided combatant battle, which would be a civil or ethnic war. In such an instance, genocide is unlikely to occur since the perpetrators must allocate their personnel and resources for fighting an effective resistance. Thus, for genocide to be executed, the perpetrators need unmatched, one-sided political authority and territorial control.

But how much structural control is necessary for genocide to occur? In Kalyvas' seminal work on civil war violence, he argues that "selective violence can only take place in those areas where control is complete enough for denouncers to denounce, but not so complete that defectors have either fled or simply ceased to be of concern to the political actor." ${ }^{31}$ In other words, Kalyvas argues that we should expect civil war violence under areas of dominant control. ${ }^{32}$ Establishing dominant control in civil wars is useful for two reasons: First, civil wars are armed conflicts between groups within a state. The actors involved, as noted by Kalyvas, may involve combatants and noncombatants. However, the main purpose of the violence is not the physical extermination of a group from a specified territory, but rather their compliance. Second, in civil wars, the actors - incumbents or insurgents - who have dominant control have already placed the target group under their authority. Their goals have been effectively met and the escalation of violence is less likely to occur.

In genocide, the presence of dominant control is not enough. To escalate and radicalize violence, perpetrators need to establish complete control. If perpetrators seek to physically exterminate an out-group from a specified territory, then they will need to display more control than needed in civil wars to achieve their goals. Unlike civil wars, placing the out-group under your authority does not achieve the goals in mind. The goal is purity, a utopian society that can rid itself of an illegitimate group altogether, and complete control increases the likelihood of exclusionary ideologies coming to fruition.

Kalyvas argues that violence during civil wars may be perpetrated under instances of complete control if rival actors are engaged in indiscriminate rather than selective violence. I argue that complete control is also more likely when perpetrators engage in extreme selective violence, or genocide..$^{33}$ What makes genocide selective is not the private information actors receive about individuals, the basis for civil war violence, but rather two important factors: the identification

\footnotetext{
${ }^{30}$ Monica Toft, The Geography of Ethnic Violence: Identity, Interests, and Indivisibility of Territory (Princeton, NJ: Princeton University Press, 2003), 18-19.

${ }^{31}$ Kalyvas, The Logic of Violence in Civil War, 209.

${ }^{32}$ Ibid., 196-197. Kalyvas outlines Zones of Control. Zone 1 represents full control by the incumbents, while Zone 5 represents full control by the insurgents. Zone 3 represents a state of parity, while Zones 2 and 4 represent dominant control by the incumbents and insurgents, respectively.

${ }^{33}$ Ibid., 209. Kalyvas' argument centers on civil war violence, thus, he differentiates indiscriminate violence from selective violence. Actors are more likely to rely on indiscriminate violence when resources and information are unavailable, whereas those actors participating in selective violence have received the necessary information needed. My argument centers on genocide, which is a more extreme form of violence than civil wars, but nonetheless, selective. The perpetrators of genocide identify target groups and members within those target groups for extermination. This
} 
of members belonging to the out-group based on ethnic, national, racial, or religious differences and the identification of individuals within those groups - often community leaders and men of military age - who perpetrators especially want to eliminate due to their prestigious or threatening status.

Likewise, agent collaboration is equally important for violence to escalate to genocide. Genocide is a radical and cumulative process, so it is crucial to understand the behavior and policies of agents at different levels of the state. The types of agents include key decision-makers in positions of power, such as national elites, local elites, the military, paramilitary groups, and so on. Everyday civilians can and do certainly participate, but such a systematic event cannot occur without effective leadership. Thus, national elites are important because genocide is destructive, organized, and sustained violence over a particular territory that requires the participation of various actors and institutions. ${ }^{34}$ The state or group must have considerable administrative force to execute systematic massacres across a country or region. Additionally, national elites often implement strategic goals they wish to achieve. By outlining clear objectives, national elites are at the top of the chain of command and their orders are directed down to military commanders, paramilitary groups, police forces, and local civilian leadership across the country or region. Because genocide is a systematically organized event, national elites must present clear goals at various stages of the process, namely, preplanning and coordination, execution of violence over groups in specified territories, and the expulsion phase through ethnic cleansing and mass killing.

Local elites are important because they can identify the out-group members living in villages, cities, and various other localities that national elites have identified for execution. ${ }^{35}$ Local elites are also important because their participation is crucial, especially since they often live in the same territory as members of the out-group. To participate in the violence, local elites must effectively gather information on members of the group by identifying important community members academics, business leaders, medical professionals, politicians, and religious figures - that must be eliminated. By eliminating leaders of the community, the consciousness of the out-group is depleted. Moreover, local elites need to identify whether members of the out-group have attempted to flee or gone into hiding in nearby villages. Because local elites are familiar with their specified localities, the ability to capture and place members of the out-group into concentration camps is very useful before ultimately deciding whether to forcibly remove or kill them. Lastly, local elites are tasked with national policies, but their responsibility to execute these policies may vary as they see appropriate for their localities. Thus, genocide requires the persistent interaction between agents at different levels of the state. Agent collaboration also accounts for the overemphasis on the national level as seen in previous studies. National elites are crucial to understanding genocide, but the dynamic nature of genocide, especially variation in intensity and timing, indicates that a greater emphasis must be placed on the local level and local actors.

In sum, my theory is a two-step approach that can be used to account for meso-level dynamics of genocide. The previous literature offers important insights into why genocide occurs; however, two points are worth noting. First, exclusively, neither has the explanatory power to account for the multifaceted nature of genocide. Genocide is far too complicated to be reduced to either strategic or ideological arguments. Second, mutually, both contribute to the absence or presence of genocide by effectively establishing scope conditions for "at-risk" cases. These scope conditions give scholars a realistic universe of cases to examine. By examining these cases, the presence of structural control and agent collaboration offers insight into how and why violence escalates and radicalizes to genocide. Once elites have political authority, territorial bases, and are coordinating their efforts at different levels of the state, then the likelihood of genocide increases. Together, these variables establish a feedback loop, whereby agent collaboration helps establish structural control and greater structural control incentivizes agents to collaborate.

illustrates that genocide is highly selective, but also extremely violent and one-sided. Therefore, to achieve such extreme violence, actors need to be completely in control.

${ }^{34}$ Straus, Retreating from the Brink, 350.

${ }^{35}$ Ibid., 351 


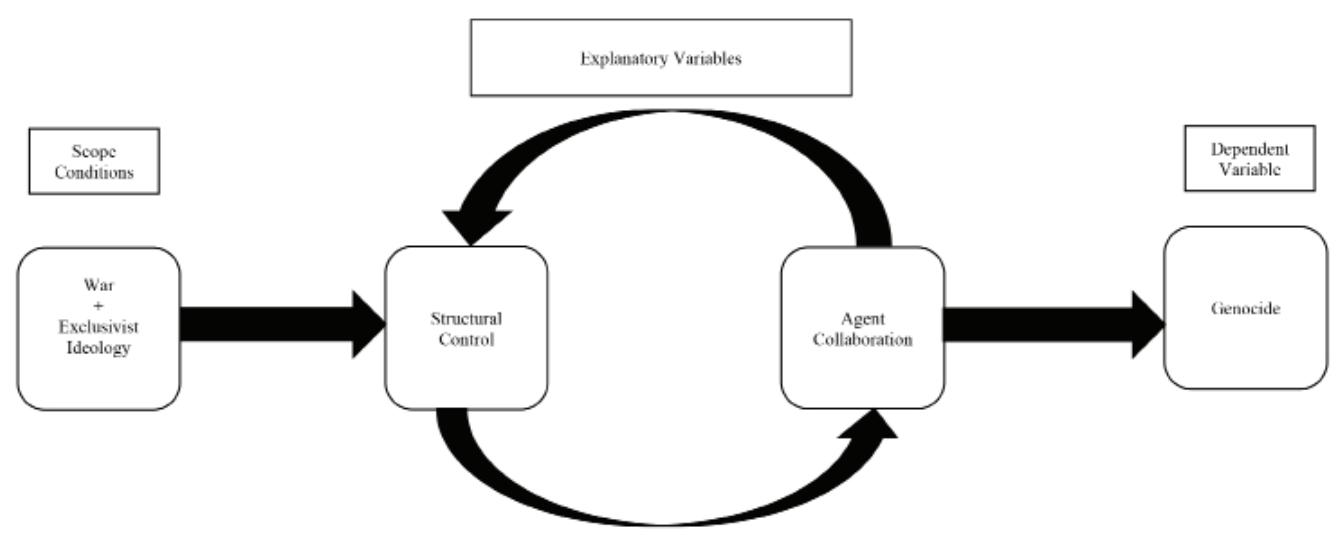

Figure 2. Meso-Level Dynamics

\section{Methods, Sources, and Case Selection}

I employ a within-case analysis of the municipality of Prijedor. The case study approach is a thorough study of a single unit or a small number of units. ${ }^{36}$ Since my analysis is focused on a single-case, I do not have the advantage of randomization afforded to large-n scholars. Instead, I rely on the selection procedures available to small-n scholars. I employ what Jack Levy calls the Theory-Guided Case Study. This case study "aims to explain and/or interpret a single historical episode rather than to generalize beyond the data." ${ }^{37}$ Additionally, theory-guided case studies are "explicitly structured by a well-developed conceptual framework that focuses attention on some theoretically specified aspects of reality and neglects others." 38

I use both secondary and primary sources, particularly, court documents provided by the International Criminal Tribunal for the Former Yugoslavia. The archives are extensive and include evidence, testimonies, and judgements from cases over two decades. Furthermore, reports prepared by the United Nations Security Council, newspaper clippings, speeches, and secondary sources are used to complement the court documents.

I seek to apply the theoretical insights previously mentioned to a significant, but underexplored historical case. This allows for greater in-depth understanding, a key benefit of the qualitative approach in the social sciences. In the case study approach, there are nine selection techniques identified: typical, diverse, extreme, deviant, influential, crucial, pathway, most-similar, and most-different cases. I employ the extreme case selection technique, which identifies cases for their extreme value on the independent or dependent variable. ${ }^{39}$ Within the political violence universe, genocide would be an extreme outcome as highlighted by both its intensity and level of group-targeting. Relatedly, the positioning of Prijedor in Quadrant C makes it an appropriate and important case for investigation.

\section{Prijedor}

Prijedor is a municipality located in northwestern Bosnia in the Bosanska Krajina region. It is situated between the town of Sanski Most to the south, the Bosnian-Croatian border towns of

\footnotetext{
${ }^{36}$ John Gerring, "The Case Study: What It Is and What It Does," in The Oxford Handbook of Political Science, ed. Robert E. Goodin (Oxford: Oxford University Press, 2009), 7.

${ }^{37}$ Jack Levy, “Case Studies: Types, Designs, and Logics of Inference," Conflict Management and Peace Science 25, no. 1 (2008), 4, accessed July 30, 2019, https://doi.org/10.1080/07388940701860318.

${ }^{38}$ Ibid., 4 .

${ }^{39}$ John Gerring, Case Study Research: Principles and Practices (Cambridge: Cambridge University Press, 2007), 89, 101-105. One could make the argument that cases could fall into multiple types, but the extreme case is the most relevant for this analysis.
} 
Bosanski Novi to the west and Bosanska Dubica to the north, and the regional capital of Banja Luka to the east. Prior to the 1992 referendum - declaring Bosnian independence from Yugoslavia - the census of 1991 accounted for a total population of 112,740. The population was ethnically intermixed; Bosnian Muslims made up 44 percent of the population, while Bosnian Serbs made up 42.5 percent of the population. ${ }^{40}$ This drastically changed as a result of the Greater Serbia campaign. By June 1993, the total population was 65,551. Bosnian Serbs made up 82 percent of the total population, while the Bosnian Muslim population was reduced to just under 10 percent. ${ }^{41}$

\section{Scope Conditions}

Tensions between the Bosnian Muslims and Bosnian Serbs escalated with the ascension of Radovan Karadžić to political power. If Slobodan Milošević was the mastermind behind the Yugoslav Wars, then Karadžić can be credited for bringing the Greater Serbia campaign to fruition within Bosnia. With a resounding speech to the Bosnian Assembly on October 14, 1991, Karadžić used his political grandeur to threaten the Bosnian Muslim goal of independence.

Do not think that you will not lead Bosnia and Herzegovina into hell, and do not think that you will not perhaps lead the Muslim people into annihilation, because the Muslims cannot defend themselves if there is war - How will you prevent everyone from being killed in Bosnia and Herzegovina? ${ }^{42}$

Karadžić gave a harrowing account of the consequences of possible secession, but he echoed more xenophobic sentiments in private in the lead up to the war. Around the time he gave his speech, Karadžić also met with Warren Zimmerman, the last Ambassador to Yugoslavia, and blamed the "chronic dishonesty" of the Muslims on their leader Izetbegović's Islamic faith. Stating, "they're prone to oriental despotism. They're always cheating us. We can't stand it anymore." Ambassador Zimmerman noted that the most startling takeaway he had from that conversation was Karadžić's portrayal of Izetbegović as a secessionist, even though he was responsible for the creation of a Serbian autonomous region prior to any Bosnian secession. ${ }^{43}$

Following Karadžić's speech, the Bosnian Parliament passed a resolution on independence the following day. Immediately after, the Serb Democratic Party (SDS) discussed the steps needed to achieve the "homogenization of Serb people and territories." 44 The top priorities included establishing a separate Bosnian Serb Assembly and holding a plebiscite exclusively for Serbs to determine whether they wanted to remain in Yugoslavia. By October 24, 1991, the Assembly of the Serb People of Bosnia and Herzegovina was established, and by January 9, 1992, the Serbs created the Republic of the Serb People of Bosnia and Herzegovina (later renamed Republika Srpska). ${ }^{45}$

In Prijedor, the Bosnian Serb leadership established local measures by effectively creating parallel governing institutions. This signaled that the Bosnian Serb leadership was not supportive of the Bosnian independence movement, and therefore, on January 17, 1992, the newly established Prijedor Serb Assembly unanimously voted to join the greater Serbian Autonomous Oblast of Bosanska Krajina (ARK). ${ }^{46}$ Following the declaration of Bosnian independence on March 1, 1992, three crucial factors made Prijedor an "at-risk" case.

\footnotetext{
${ }^{40}$ Zavod Za Statistiku Bosne I Hercegovina, Ethnic Composition of Bosnia-Herzegovina Population by Municipality ad Settlements, 1991. Census, Bilten no. 234 (Sarajevo, 1991), accessed March 27, 2019, http://josip.purger.com/other/bih/ index.htm.

${ }^{41}$ UNSC, Report of the United Nations Commission of Experts Established Pursuant to United Nations Security Council Resolution 780, December 28, 1994 (UN Doc: S/1994/674/Annex V, The Prijedor Report), 7.

${ }^{42}$ Radovan Karadžić, "Speech to the Parliament of Bosnia and Herzegovina," (speech, Sarajevo, Bosnia and Herzegovina, October 14, 1991), accessed February 1, 2019, http://www.slobodan-milosevic.org/documents/KaradzicSpeech101591. pdf.

${ }^{43}$ Warren Zimmerman, Origins of Catastrophe: Yugoslavia and Its Destroyers (New York: Time Books, 1999), 175.

${ }^{44}$ Bećirević, Genocide on the Drina River, 57.

${ }^{45}$ Ibid., 58-61.

${ }^{46}$ Prosecutor v. Milomir Stakić, Judgement, July 31, 2003, IT-97-24-T, para. 62.
} 
First, the Croatian War was a precursor for the type of violence that would unfold in Bosnia. The Yugoslavia National Army (JNA) needed conscripts, but many Bosnian Muslims and Bosnian Croats chose not to respond to the call in the neighboring country. This created a situation where most of the national Yugoslav military was composed of soldiers of Bosnian Serb descent, creating insecurity among the non-Serb population of Prijedor. ${ }^{47}$ Second, a rise in propaganda produced fear among the non-Serb community. Radio and TV broadcasts blocked content coming in from Croatia and Sarajevo, and only permitted broadcasts from Serbia or the Bosnian Serb hub of Banja Luka. At the direction of the Bosnian Serb leadership, Radio Prijedor accused Bosnian Muslim doctors of seeking to reduce the Bosnian Serb birth rate by either sterilizing women or giving pregnant women "special injections" so they would be limited to only giving birth to girls. Relatedly, Bosnian Serb citizens were encouraged to accept a policy of discrimination and exclusion against their non-Serb neighbors or fear the consequence of being labeled "traitors." 48 Third, by the time war erupted in the cosmopolitan capital of Sarajevo on April 6, 1992, the JNA, now predominately Serb, deployed nearly 55,000 troops to Bosnia. ${ }^{49}$ Around the same time, the Bosnian Serbs ramped up their offensive in strategic locations across eastern Bosnia, including Bijeljina, Bratunac, Foča, and Zvornik. War officially commenced in Bosnia, and the stage was set for the violence that would follow in Prijedor a few weeks later.

\section{Structural Control}

The Bosnian Serb leadership took notable steps in establishing overwhelming political authority and territorial bases throughout the municipality. Politically, the Bosnian Serbs effectively rivaled and ultimately replaced, the original governing institutions with the creation of two bodies: The Bosnian Serb Assembly of Prijedor and the Prijedor Crisis Staff.

The Bosnian Serb Assembly of Prijedor was the local equivalent to the declaration of Republika Srpska. By forming the Assembly, the local Bosnian Serb leadership joined the greater ARK, composed of Bosnian Serb districts throughout northwest Bosnia. These districts were selfproclaimed and were formed as a response to the Bosnian declaration for independence. With the command and structure established nationally - Republika Srpska - and the creation of the Assembly in Prijedor, the next steps involved linking the various regions across Bosnia under the unified Greater Serbia objectives. To achieve this, the Bosnian Serb leadership set up similar institutions called "Crisis Staffs." Karadžić set guidelines ordering all municipal and regional committees of the SDS to work undercover in preparation for possible war. The Crisis Staffs were ordered to cooperate with the commanders of the JNA, members of the SDS, and the Assembly of the Bosnian Serbs in each locality. According to expert testimony, "the Crisis Staff coordinates functions of authorities with the objective of defending the territory, securing the safety [of people and property], establishing the authority and organizing areas of life and work...the Crisis Staff is obliged to collect information on conditions in the field." 50

Territorially, the Bosnian Serbs outpowered the Bosnian Muslims in Prijedor in three ways: through the "ethnicization" of the JNA, the arming of Bosnian Serb residents, and the formation of territorial headquarters for Bosnian Serb operations in Banja Luka.

Nationally, the JNA was relatively multiethnic and composed of soldiers from the various republics prior to 1991. But, by March 1992, except for a minority of Montenegrin soldiers, the army was 90 percent Serb. ${ }^{51}$ With the federal army in complete control by the Bosnian Serbs, the JNA began to disarm Bosnian troops and argued that peace and stability could only be secured by handing over weapons. Locally, efforts were then made by the JNA to distribute weapons

\footnotetext{
${ }^{47}$ Prosecutor v. Radovan Karadžić, Judgement, March 24, 2016, IT-95-5/18, para. 1582.

${ }^{48}$ Ibid.

${ }^{49}$ Zimmerman, Origins of Catastrophe, 185-186; John F. Burns, “Understanding and Letting Loose: Historical Hatreds in the Balkans," New York Times, May 17, 1992, accessed March 25, 2019, https://www.nytimes.com/1992/05/17/ weekinreview/conversations-radovan-karadzic-understanding-letting-loose-historic-hatreds.html.

${ }^{50}$ Bećirević, Genocide on the Drina River, 10.

${ }^{51}$ Ibid., 73.
} 
to the Prijedor Territorial Defense units and the Bosnian Serb citizens. ${ }^{52}$ Their Bosnian Muslim counterparts received outdated weapons often containing the wrong ammunition, whereas Bosnian Serb residents were equipped by JNA military helicopters that would land several times a day in Serb-concentrated villages of Prijedor. Insofar as weapons were concerned, "only four percent of the Muslims in Prijedor have been licensed to have weapons. Many Muslim and Croats had their applications for a license to carry turned down without any reason given." ${ }^{53}$ The pretext for weapons distribution was that it was a necessary defense against the "enemies of the people" or the Muslim extremists and the Croatian fascists - Ustaša. ${ }^{54}$ The weapon distribution phase gave Bosnian Serbs two territorial advantages locally. First, it was coupled with the establishment of checkpoints, which were vital for Bosnian Serb efforts seeking to control the movement of the Bosnian Muslim population in Prijedor. Second, Prijedor had now contained the largest concentration of former JNA weapons and the JNA was conducting training programs for Bosnian Serb residents throughout the municipality ${ }^{55}$ Most significantly, the Bosnian Serbs established their territorial headquarters in Banja Luka - only 55 kilometers east of Prijedor. The region had a well-organized chain of command, and because of the war in Croatia and the proximity to the border, many soldiers were already situated in Banja Luka and ready for the offensive in Prijedor. ${ }^{56}$

\section{Agent Collaboration}

Structural control incentivized agent collaboration in the Prijedor municipality, whereby elites at various levels of the state pooled their efforts for the Greater Serbia objectives. At the same time, the ability of elites to collaborate helped establish structural control. This feedback loop is evident when analyzing the actions of Karadžić.

Karadžić was crucial in various stages. During stage one, or the propaganda and nationalist rhetoric stage, he was the catalyst for a Bosnian Serb state in a time of deep divide and increasing ethnic tensions. He founded the SDS in Bosnia in 1989 and unified the Bosnian Serb population in the face of Bosnian secession from Yugoslavia. His rhetoric was stern, signaling to the Bosnian Muslims that their efforts would lead to bloodshed, disappearance, and ultimately extinction. ${ }^{57}$ All this propelled him to the helm as the first President of Republika Srpska. During stage two, the preplanning and coordination phase, Karadžić assured that the formation of the Crisis Staffs was executed across the country and that these Crisis Staffs coordinate their efforts with the local civilian leadership and military units. During stage three, the execution of the Greater Serbia campaign, Karadžić, along with members of the Bosnian Serb leadership, operated under commander's intent, best summed up as

it is unlikely that Milošević or Karadžić could or need have known about or controlled the details of all operations. Although in some instances direct guidance on what to do was not available, in many cases, 'commander's intent' was more likely used, whereby the leadership could set certain policy goals and assume that subordinates would have the latitude to use virtually any means to achieve them. Subsequent claims by the Serbian and Bosnian Serbian leadership, that they had no control, seem to have been intended primarily to provide convenient plausible denial to the outside world without hampering their policy. ${ }^{58}$

\footnotetext{
${ }^{52}$ Territorial Defense Units were a separate part of the military dating back to the time of the Federal Republic of Yugoslavia. These forces were set up as a "home guard," or the equivalent of reserve forces. In Prijedor, much like everywhere else, these units were composed of Bosnian Serbs, but some Bosnian Muslim also had their own TO units.

${ }^{53}$ UNSC, Report of the United Nations Commission of Experts Established Pursuant to United Nations Security Council Resolution 780, December 28, 1994 (UN Doc: S/1994/674/Annex V, The Prijedor Report), 25.

${ }^{54}$ Ibid., 30.

${ }^{55}$ Prosecutor v. Radovan Karadžić, Judgement, March 24, 2016, IT-95-5/18, para. 1583.

${ }^{56}$ UNSC, Report of the United Nations Commission of Experts Established Pursuant to United Nations Security Council Resolution 780, December 28, 1994 (UN Doc: S/1994/674/Annex V, The Prijedor Report), 26-27.

${ }^{57}$ Prosecutor v. Radovan Karadžić, Appeals Chamber Judgement, July 11, 2013, IT-95-5/18-AR98bis.1, para. 98.

${ }^{58}$ Norman Cigar, Genocide in Bosnia: The Policy of Ethnic Cleansing (College Station, TX: Texas A\&M University Press, 1995), 48.
} 
With Karadžić at the top of the hierarchal structure, it was the responsibility of local leadership to carry out the command, and in Prijedor this was achieved by the Crisis Staff, Bosnian Serb police, JNA units, and participation of paramilitary groups. According to UN Reports, efforts by the JNA and various paramilitary units were "fully synchronized...all the major Serbian operations started with heavy artillery barrages or the use of tanks as operated by the regular army, and were immediately followed by the onslaught of paramilitary and irregular units working in tandem with regular army infantry." Moreover, the UN investigators concluded that "there is not one single report to the effect that there was ever a paramilitary or irregular unit working to obstruct or even slightly hinder the objectives of the regular army." ${ }^{59}$

This was made possible due to the highly organized efforts of the Crisis Staffs. In Prijedor, the Crisis Staff established control over the municipality by arming local Bosnian Serbs, blocking communications of non-Serbs, destroying multiethnic relations throughout the community by spreading propaganda, and providing logistical support to the military through the takeover of industry and production units. ${ }^{60}$

Most importantly, the Crisis Staff implemented the takeover of Prijedor on April 30, 1992. Along with brigades from the JNA forces stationed in Banja Luka and members of the Bosnian Serb police, the Crisis Staff initiated a coup d'état with little to no resistance. By early morning, the Bosnian Serb soldiers established complete control over the Municipal Assembly building, the police station, courthouse, bank, post office, and radio station. That same day, Bosnian flags were removed from all municipal buildings and replaced with Serbian flags. Non-Serb policemen were disarmed and asked to pledge loyalty to secure their employment or face termination. ${ }^{61}$

In the weeks following the takeover, the Crisis Staff, JNA, and paramilitary units increased exclusivist measures against Bosnian Muslims and other non-Serbs by firing them from work, prohibiting children from attending school, and restricting the freedom of movement throughout the municipality. These measures extended to the local media too, specifically Radio Prijedor and the local newspaper Kozarski Vjesnik. Both served as vehicles of propaganda for the new Bosnian Serb leadership. Radio Prijedor broadcasted Serbian nationalist or Četnik songs, attacked members of the Party of Democratic Action (the Bosnian Muslim political party), and issued statements comparing Bosnian Muslims to Islamic fundamentalists who were seeking to establish control in the area to wage genocide against Bosnian Serb citizens. ${ }^{62}$

The most haunting measure came on May 30, when Radio Prijedor demanded that all Bosnian Muslims and other non-Serbs mark their homes with white flags and themselves with white armbands; a sign of surrender. ${ }^{63}$ It was the first time since 1939 - when the Nazis ordered Polish Jews to wear the Star of David on their sleeve - that individuals of an ethnic or religious group were marked for mass deportation and mass killing. With overwhelming structural control, and coordination at all levels of the state, the Bosnian Serb leadership escalated their offensive that day. Some of these individuals were taken to notorious concentration camps like Keraterm, Omarska, and Trnopolje, while the remaining victims were subject to harassment and beatings. The beginning of the Greater Serbia campaign in Prijedor was underway.

Genocide

Prijedor, along with other strategic municipalities extending across eastern and northwestern Bosnia, was part of the Serbian Arc. The goals were twofold. From a political standpoint, the objective was to unite Serbs living in Serbia, Bosnia, and Croatia under a common government.

\footnotetext{
${ }^{59}$ UNSC, Report of the United Nations Commission of Experts Established Pursuant to United Nations Security Council Resolution 780, December 28, 1994 (UN Doc: S/1994/674/Annex V, The Prijedor Report), 63-64.

${ }^{60}$ Human Rights Watch, The Unindicted: Reaping the Rewards of "Ethnic Cleansing" in Prijedor, January 1, 1997, 14, accessed March 25, 2019, https://www.hrw.org/report/1997/01/01/unindicted/reaping-rewards-ethnic-cleansing-prijedor.

${ }^{61}$ Prosecutor v. Milomir Stakić, Judgement, July 31, 2003, IT-97-24-T, paras. 76-82; Prosecutor v. Radovan Karadžić, Judgement, March 14, 2016, IT-95/18-T, paras. 1592-1593; 1597.

${ }^{62}$ UNSC, Report of the United Nations Commission of Experts Established Pursuant to United Nations Security Council Resolution 780, December 28, 1994 (UN Doc: S/1994/674/Annex V, The Prijedor Report), 9.

${ }^{63}$ Ibid., 63-64.
} 
From a territorial standpoint, this would be achieved by physically linking territories throughout Bosnia, Croatia, and Serbia into a common region; Greater Serbia. Hence, resembling an arc shape. These two strategic goals were part of six goals emphasized by Karadžić at the 16th session of the Assembly of the Serbian People in Bosnia and Herzegovina.

The first goal is separation from the other two national communities - separation of states. Separation from those who are our enemies and who have used every opportunity, especially in this century, to attack us, and who would continue with such practices if we were to continue to stay together in the same state.

The second strategic goal...is a corridor between Semberija and Krajina. That is something for which we may be forced to sacrifice something here and there, but is of the utmost importance for the Serbian people, because it integrates the Serbian lands...which will integrate us, which will provide us unimpeded flow from one part of our state to another. ${ }^{64}$

Greater Serbia represented the so-called utopia, or at least the desire to purify what is historically and rightfully Serbian from threatening enemies; Bosnian Muslims and other non-Serbs. This exclusionary, irredentist ideology was the goal in Prijedor, but to achieve it, the Bosnian Serbs had to go beyond the traditional theater of warfare. This required the Bosnian Serbs to enter the groupselective and group-destructive phase of genocide.

The process to genocide escalated after the takeover of Prijedor and the subsequent exclusionary targeting of Bosnian Muslims and other non-Serb residents. Once the Bosnian Serbs were able to disrupt everyday life, without any means of an effective counter-resistance, they shifted their efforts to the surrounding villages and the creation of concentration camps.

The Bosnian Serb leadership attacked the predominantly Bosnian Muslim village of Hambarine on May 22. An ultimatum was issued over Radio Prijedor ordering several individuals to surrender themselves and all their weapons or face possible consequences. The ultimatum was not met, and the attack commenced the next day. The units responsible for the attack included the 1st Krajina Corps, the $6^{\text {th }}$ Krajina Brigade, the $43^{\text {rd }}$ Motorized Brigade, the Bosnian Serb police, and members from various paramilitary groups under the direction of the Crisis Staff. ${ }^{65}$ Following the attack on Hambarine, similar events unfolded in the town of Kozarac - encompassing the villages of Kamičani, Kozaruša, Sušići, Brdjani, and Babići. The Bosnian Serb leadership issued an ultimatum for weapons surrender and soon thereafter, an attack was initiated consisting of approximately 5,000 perpetrators. Among the group of perpetrators were the infamous paramilitary units led by Željko Ražnatović (Arkan) and Vojislav Šešelj. ${ }^{66}$

The attack on Kozarac lasted until May 26 and the Bosnian Serbs achieved their ethnic purification of the mostly Bosnian Muslim enclave of 25,000 residents. On that same day, Bosnian Serb aggressors moved their tanks and loudspeakers into town and began crying out, "Muslims get out! Muslims get out! Surrender and everyone will be safe!" Homes were destroyed, some even set on fire with residents still in them, and Bosnian Muslims agreed to terms of surrender: If they wished to evacuate Kozarac and accept surrender, they would need to form a column. What they did not know at that time was that they were being subjected to a "carefully planned and coordinated attack designed not only to remove the population, but to liquidate its leaders and destroy homes so that the 'cleansing' would be irreversible." ${ }^{\prime 67}$ Thousands of Bosnian Muslims emerged from the

\footnotetext{
${ }^{64}$ Prosecutor v. Radovan Karadžić, Judgement, March 14, 2016, IT-95/18-T, para. 2857.

${ }^{65}$ Prosecutor v. Milomir Stakić, Judgement, July 31, 2003, IT-97-24-T, paras. 131-136; Prosecutor v. Radoslav Brdanin, Judgement, September 1, 2004, IT-99-36-T, para. 626.

${ }^{66}$ Prosecutor v. Radovan Karadžić, Judgement, March 14, 2016, IT-95/18-T, para. 1619; Prosecutor v. Radoslav Brdanin, Judgement, September 1, 2004, IT-99-36-T, para. 627; Prosecutor v. Milomir Stakić, Judgement, July 31, 2003, IT-97-24-T, para. 142. Arkan was a Serbian career criminal, wanted by INTERPOL throughout the 1970s and 1980s, and indicted for crimes against humanity during the Yugoslav Wars.

${ }^{67}$ Mary Battiata, “A Town's Bloody Cleansing," Washington Post, November 2, 1992, accessed March 27, 2019, https://www. washingtonpost.com/archive/politics/1992/11/02/a-towns-bloody-cleansing/3c5bbcee-7c9c-4669-82b7-bcec86c01237/.
} 
forest waving white flags of surrender. Additionally, the town's elite was identified, including judges, politicians, police officers, restaurant owners, factory managers, and local sports heroes, for removal and transportation to the established concentration camps.

Whether in Hambarine, Kozarac, Prijedor proper, or other Bosnian Muslim enclaves, the same pattern unfolded in late May and early June. The men were brought to concentration camps to be detained, and in many cases, tortured and killed. The women, children, and elderly men were transported to Trnopolje, for immediate deportation or prolonged captivity. To sum up, "In Prijedor town, Stari Grad [Old Town] and adjacent areas were 'ethnically cleansed' first, that is already on May 30, 1992. Other parts of the town were 'cleansed' in raids or in connection with ransacking the following days." ${ }^{68}$ By this point, the Bosnian Serb leadership moved onto the last phase of the Greater Serbia objectives - mass deportation and mass killing. The former was largely the responsibility of the camp at Trnopolje, while camps Keraterm and Omarska were primarily used for detention, subjugation, expulsion, and in extreme cases, death.

The detainees at Keraterm and Omarska were subject to serious mistreatment and abuse, including lack of food and medical care, poor hygiene and overcrowding, physical abuse and interrogations, and death. Both camps were established by the Crisis Staff and were under the command of the Bosnian Serb military and police officers. Although records at Omarska were inadequate, estimates indicated that around 700 people were killed..$^{69}$ The camp was eventually shut down on August 7, following a visit from international journalist Roy Gutman. Gutman was the first to break the story by reporting on the maltreatment and killings of detainees. Following Gutman's reporting, Ed Vulliamy, a British journalist, described what he saw at Omarska.

The men are at various stages of human decay and affliction; the bones of their elbows and wrists protrude like pieces of jagged stone from the pencil thin stalks to which their arms have been reduced...There is nothing quite like the sight of the prisoner desperate to talk and to convey some terrible truth that is so near yet so far, but who dares not. Their stares burn, they speak only with their terrified silence, and eyes inflamed with the articulation of stark, undiluted, desolate fear-without-hope. ${ }^{70}$

Keraterm was reported to have held as many as 1,500 detainees at any given time, primarily in four separate rooms. Keraterm was also the site of the July 24 massacres. Leading up to the event, detainees originally in Room 3 were moved to Rooms 2 and 4, clearing the room for Bosnian Muslim men who arrived from the Brdo area on July 20 or 21. Other witnesses indicated that the detainees were stripped of their documents and forbidden from interacting with detainees in other rooms. ${ }^{71}$ On the night of July 24, Armed guards entered the camp and placed a machine-gun on top of the table facing Room 3, resulting in the massacre of nearly 200 Bosnian Muslim men. ${ }^{72}$ According to a Bosnian Muslim witness, he was in Room 2 when the massacre had occurred, and the following day, several survivors at the camp were instructed to pile dead and wounded bodies into a truck that was never seen again. ${ }^{73}$

${ }^{68}$ UNSC, Report of the United Nations Commission of Experts Established Pursuant to United Nations Security Council Resolution 780, December 28, 1994 (UN Doc: S/1994/674/Annex V, The Prijedor Report), 58.

${ }^{69}$ Roy Gutman, A Witness to Genocide: The First Inside Account of the Horrors of Ethnic Cleansing in Bosnia (Boston: Element Books, 1993), 91-92. Gutman's numbers indicated between 1,200 to 2,000, but more recent and accurate estimations are closer to 700. See Albina Sorguc, "Bosnians Commemorate Victims of Notorious Omarska Camp," Balkan Transnational Justice, August 6, 2018, accessed February 12, 2020, https://balkaninsight.com/2018/08/06/bosnians-commemoratevictims-of-notorious-omarska-camp-08-06-2018/.

${ }^{70}$ Ed Vulliamy, Seasons in Hell: Understanding Bosnian's War (London: St. Martin's Press, 1994), 102.

${ }^{71}$ Prosecutor v. Radovan Karadžić, Judgement, March 14, 2016, IT-95/18-T, para. 1807.

72 Prosecutor v. Milomir Stakić, Judgment, July 21, 2003, IT-97-24-T, paras. 204-206.

${ }^{73}$ Joseph R. Biden, Jr., To Stand Against Aggression: Milosevic, the Bosnian Republic, and the Conscience of the West: A Report to the Committee on Foreign Relations United States Senate (Washington, DC: U.S. GPO, 1993), 47; UNSC, The Final Report of the Commission of Experts Established Pursuant to Security Council Resolution 780, December 28, 1994 (UN Doc. S/1994/674/Annex VIII, Prison Camps), 226. It is reported that detainees in Room 3 were given the worst treatment, including torture and killings. 
As for Trnopolje, it was initially established for the mass deportation of women, children, and the elderly. But, after the closing of Keraterm and Omarska, Bosnian Muslim men were also transferred to the camp. Conditions improved slightly in late August due to the international outcry, but the situation as a whole remained dire. For example, on August 21, some detainees were even subject to mass killing. A convoy stopped at Trnopolje, where mostly male detainees but also some women and children were loaded on for transfer. As the convoy made its way to the town of Skender Vakuf, men of military age were separated from the women and children and ordered to get on two empty buses. The buses, which included some 250 detainees, stopped at a nearby cliff facing a deep gorge. It was reported that approximately 200 dead bodies were found near Mount Vlašić after the August 21 massacre. ${ }^{74}$

\section{Conclusion}

By the end 1992, the goals of genocide had been achieved due to the effective deportation and extermination of Bosnian Muslims and non-Serbs. By June 1993, the Bosnian Muslim population accounted for just under 10 percent of the total population in Prijedor. By 1995, this number was down to 5 percent, a drastic demographic change when compared to 44 percent in $1991 .{ }^{75}$ As the international community was fixated on the events occurring in Sarajevo, the Bosnian Serb leadership effectively established dominance in strategic territory for purposes of securing a homogenous Serb population. What occurred in the Prijedor municipality over the spring and summer of 1992 can best be characterized as the following:

The 'ethnic cleansing' is the core of the Serbian military operations in Bosnia. It may even be argued, as some observers do, that the events in Sarajevo - where there is a more traditional theatre of war with all its horrors - are staged, in part at least, to take away international attention from the eradication of entire ethnic groups in areas where there has not even been any real war, only tremendous abuses of military power - such as in Opstina Prijedor. ${ }^{76}$

By focusing on the meso-level, a more in-depth understanding of Prijedor was elucidated. Particularly, the presence of structural control and agent collaboration were crucial for explaining the events that unfolded in Prijedor. War and exclusivist ideology created a hostile situation. After the siege of Sarajevo and the onset of violence in eastern Bosnia, it was only a matter of time until violence reached Prijedor. But these were scope conditions, or "at-risk" factors. To account for the escalation and radicalization of violence to genocide, the following variables were necessary: overwhelming political authority, territorial presence, and a highly coordinated effort between national and local elites. These factors brought the Greater Serbia goals to life, an accounted for the high-level of intensity and group-targeting witnessed in Prijedor. Moving forward, two questions remain: Were these same patterns present across other municipalities of the Serbian arc? And if so, what municipalities were able to overcome or avoid genocide and why? These questions are a logical next step I plan to unpack in future studies to account for cross-case comparisons at the subnational level.

\section{Bibliography}

Acquaviva, Guido. "Robert Donia, From the Republika Srpska Assembly 1991-1996: Excerpts from Delegates' Speeches at the Republika Srpska Assembly as Body of Evidence for the International Criminal Tribunal at The Hague." Journal of International Criminal Justice 11, no. 1 (September 2013), 931-951. Accessed March 25, 2019. Doi: 10.1093/jicj/mqt049

\footnotetext{
${ }^{74}$ Prosecutor v. Radovan Karadžić, Judgement, March 14, 2016, IT-95/18-T, paras. 1846-1847.

${ }^{75}$ UNSC, Report of the United Nations Commission of Experts Established Pursuant to United Nations Security Council Resolution 780, December 28, 1994 (UN Doc: S/1994/674/Annex V, The Prijedor Report), 7; Prosecutor v. Radovan Karadžić, Judgement, March 14, 2016, IT-95/18-T, para. 1913.

${ }^{76}$ UNSC, Report of the United Nations Commission of Experts Established Pursuant to United Nations Security Council Resolution 780, December 28, 1994 (UN Doc: S/1994/674/Annex V, The Prijedor Report), 101.
} 
Ball, Patrick, Ewa Tabeau, and Philip Verwimp. The Bosnian Book of the Dead: Assessment of the Database (Full Report). Falmer, United Kingdom: The Institute of Development Studies, 2007. Accessed March 27, 2019. http://www.hicn.org/wordpress/wp-content/uploads/2012/07/ rdn5.pdf.

Battiata, Mary. “A Town's Bloody Cleansing." Washington Post, November 2, 1992. Accessed March 27, 2019. https://www.washingtonpost.com/archive/politics/1992/11/02/a-towns-bloodycleansing/3c5bbcee-7c9c-4669-82b7-bcec86c01237/.

Bećirević, Edina. Genocide on the Drina River. New Haven, CT: Yale University Press, 2014.

Biden, Jr. Joseph R. To Stand Against Aggression: Milosevic, the Bosnian Republic, and the Conscience of the West: A Report to the Committee on Foreign Relations United States Senate. Washington, DC: U.S. GPO, 1993.

Bloxham, Donald and A. Dirk Moses. The Oxford Handbook of Genocide Studies. Oxford: Oxford University Press, 2010.

Burns, John F. "Understanding and Letting Loose: Historical Hatreds in the Balkans." New York Times, May 17, 1992. Accessed March 25, 2019. https://www.nytimes.com/1992/05/17/ weekinreview/conversations-radovan-karadzic-understanding-letting-loose-historichatreds.html.

Caspersen, Nina. Contested Nationalism: Serb Elite Rivalry in Croatia and Bosnia in the 1990s. New York: Berghahn Books, 2010.

Christia, Fotini. "Following the Money: Muslims versus Muslims in Bosnia's Civil War." Comparative Politics 40, no. 4 (2008), 461-480. Accessed March 25, 2019. Doi: 10.5129/001041508X129113 $\underline{62383390}$

Cigar, Norman. Genocide in Bosnia: The Policy of Ethnic Cleansing. College Station, TX: Texas A\&M University Press, 1995.

Fein, Helen. Accounting for Genocide: National Responses and Jewish Victimization during the Holocaust. Chicago: Chicago University Press, 1979.

Finkel, Evgeny and Scott Straus. "Macro, Meso, and Micro Research on Genocide: Gains, Shortcomings, and Future Areas of Inquiry." Genocide Studies and Prevention: An International Journal 7, no. 1 (2012), 56-67. Accessed February 1, 2019. Doi: 10.3138/gsp.7.1.56

Fujii, Lee Ann. Killing Neighbors: Webs of Violence in Rwanda. Ithaca, NY: Cornell University Press, 2009.

Geddes, Barbara. "How the Cases You Choose Affect the Answers You Get: Selection Bias in Comparative Politics." Political Analysis 2, no. 1 (1990), 131-150. Accessed March 27, 2019. Doi: 10.1093/pan/2.1.131

Gerring, John. "The Case Study: What it is and What it Does." In The Oxford Handbook of Political Science, edited by Robert E. Goodin, 1-37. Oxford. Oxford University Press, 2009.

------. Case Study Research: Principles and Practices. Cambridge: Cambridge University Press, 2007.

Gratz, Dennis. "Elitocide in Bosnia and Herzegovina and Its Impact on the Contemporary Understanding of the Crime of Genocide." The Journal of Nationalism and Ethnicity 39, no. 3 (2011), 409-424. Accessed February 13, 2020. Doi: 10.1080/00905992.2011.565318

Gutman, Roy. A Witness to Genocide: The First Inside Account of the Horrors of Ethnic Cleansing in Bosnia. Boston: Element Books, 1993.

Harff, Barbara. “No Lessons Learned from the Holocaust? Assessing Risks of Genocide and Political Mass Murder since 1955." American Political Science Review 97, no. 1 (2003), 57-73. Accessed March 27, 2019. Doi: 10.1017/S0003055403000522

Horowitz, Irving Louis. Genocide: State Power and Mass Murder. New Brunswick: Transaction, 1976. Human Rights Watch, The Unindicted: Reaping the Rewards of "Ethnic Cleansing" in Prijedor. January 1, 1997, 14. Accessed March 25, 2019. https://www.hrw.org/report/1997/01/01/unindicted/ reaping-rewards-ethnic-cleansing-prijedor.

Kalyvas, Stathis. The Logic of Violence in Civil War. Cambridge: Cambridge University Press, 2006.

Karadžić, Radovan. "Speech to the Parliament of Bosnia and Herzegovina." Speech, Sarajevo, Bosnia and Herzegovina, October 14, 1991. Accessed February 1, 2019. http://www. slobodan-milosevic.org/documents/KaradzicSpeech101591.pdf. 
Kaufman, Stuart. "Symbolic Politics or Rational Choice? Testing Theories of Extreme Ethnic Violence." International Security 30, no. 4 (2006), 45-86. Accessed March 27, 2019. Doi: 10.1162/isec.2006.30.4.45

Kiernan, Ben. Blood and Soil: A World History of Genocide and Extermination from Sparta to Darfur. New Haven: Yale University Press, 2009.

King, Charles. "The Micropolitics of Social Violence." World Politics 56, no. 1 (2004), 431-455. Accessed March 27, 2019. Doi: 10.1353/wp.2004.0016

Krain, Matthew. "State-Sponsored Mass Murder: The Onset and Severity of Genocides and Politicides." Journal of Conflict Resolution 41, no. 3 (1997), 331-360. Accessed March 27, 2019. Doi: $10.1177 \% 2 F 0022002797041003001$

Kuper, Leo. Genocide: Its Political Use in the Twentieth Century. New Haven: Yale University Press, 1981.

Levy, Jack. "Case Studies: Types, Designs, and Logics of Inference," Conflict Management and Peace Science 25, no. 1 (2008), 1-18. Accessed July 30, 2019. Doi: 10.1080/07388940701860318

Maksić, Adis. Ethnic Mobilization, Violence, and the Politics of Affect: The Serb Democratic Party and the Bosnian War. London: Palgrave Macmillan, 2017.

Marx, Anthony W. “The Nation-State and Its Exclusions.” Political Science Quarterly 17, no. 1 (2002), 103-126. Accessed March 27, 2019. Doi: 10.2307/798096

Midlarsky, Manus. The Killing Trip: Genocide in the Twentieth Century. New York: Cambridge University Press, 2005.

Sémelin, Jacques. Purify and Destroy: The Political Uses of Massacre and Genocide. London: Hurst \& Company, 2005.

Shaw, Martin. War and Genocide: Organized Killing in Modern Society. Cambridge: Polity, 2003.

Sorguc, Albina. "Bosnians Commemorate Victims of Notorious Omarska Camp," Balkan Transnational Justice, August 6, 2018. Accessed February 12, 2020. https://balkaninsight. com/2018/08/06/bosnians-commemorate-victims-of-notorious-omarska-camp-08-06-2018/.

Staub, Ervin. The Roots of Evil: The Origins of Genocide and Other Group Violence. Cambridge: Cambridge University Press, 1989.

Straus, Scott. "Destroy Them to Save Us: Theories of Genocide and the Logics of Political Violence." Terrorism and Political Violence 24, no. 4 (2012), 544-560. Accessed March 27, 2019. https:// psycnet.apa.org/doi/10.1080/09546553.2012.700611.

. Making and Unmaking Nations: War Leadership, and Genocide in Modern Africa. Ithaca, NY: Cornell University Press, 2015.

. "Retreating from the Brink: Theorizing Mass Violence and the Dynamics of Restraint." Perspectives on Politics 10, no. 2 (2012), 343-362. Accessed March 25, 2019. Doi: 10.1017/ $\underline{\mathrm{S} 1537592712000709}$

--------. The Order of Genocide: Race, Power, and War in Rwanda. Ithaca, NY: Cornell University Press, 2006.

Toft, Monica. The Geography of Ethnic Violence: Identity, Interests, and Indivisibility of Territory. Princeton, NJ: Princeton University Press, 2003.

Ulfelder, Jay and Benjamin Valentino. Assessing Risks of State-Sponsored Mass Killing. Washington, DC: Political Instability Task Force, 2008. Accessed March 27, 2019. https://papers.ssrn. com/sol3/papers.cfm?abstract id=1703426.

United Nations Security Council (UNSC). The Final Report of the Commission of Experts Established Pursuant to Security Council Resolution 780. December 28, 1994. UN Doc. S/1994/674/Annex V, The Prijedor Report.

--------. The Final Report of the Commission of Experts Established Pursuant to Security Council Resolution 780, December 28, 1994. UN Doc. S/1994/674/Annex VIII, Prison Camps.

Valentino, Benjamin. Final Solutions: Mass Killing and Genocide in the Twentieth Century. Ithaca, NY: Cornell University Press, 2004.

Varshney, Ashutosh. Ethnic Conflict and Civic Life: Hindus and Muslims in India. New Haven: Yale University Press, 2002. 
Verdeja, Ernesto. “On Situating the Study of Genocide within Political Violence." Genocide Studies and Prevention: An International Journal 7, no. 1 (2012), 81-88. Accessed March 25, 2019. Doi: $10.3138 / g s p .7 .1 .81$.

Vulliamy, Ed. Seasons in Hell: Understanding Bosnian's War. London: St. Martin's Press, 1994.

Weitz, Eric. A Century of Genocide: Utopias of Race and Nation. Princeton: Princeton University Press, 2003.

Zavod Za Statistiku Bosne I Hercegovine. Ethnic Composition of Bosnia-Herzegovina Population by Municipality ad Settlements, 1991. Census, Bilten no. 234, Sarajevo, 1991, Accessed March 27, 2019. http://josip.purger.com/other/bih/index.htm.

Zimmerman, Warren. Origins of Catastrophe: Yugoslavia and Its Destroyers. New York: Time Books, 1999. 